\title{
Large-scale electrospinning of poly (vinylalcohol) nanofibers incorporated with platelet-derived growth factors
}

\author{
B. Koprivova ${ }^{1}$, M. Lisnenko ${ }^{1,6}$, K. Solarska-Sciuk ${ }^{2}$, R. Prochazkova ${ }^{3,4}$, V. Novotny ${ }^{5}$, \\ J. Mullerova ${ }^{1,5}$, P. Mikes $^{1}$, V. Jencova ${ }^{1 *}$ \\ ${ }^{1}$ Faculty of Science, Humanities and Education, Technical University of Liberec, Studentska 1402/2, 46117 Liberec 1, \\ Czech Republic \\ ${ }^{2}$ Department of Physics and Biophysics, Wroclaw University of Environmental and Life Sciences, Norwida 25, 50-375 \\ Wroclaw, Poland \\ ${ }^{3}$ Faculty of Health, Technical University of Liberec, Studentska 1402/2, 46117 Liberec 1, Czech Republic \\ ${ }^{4}$ Regional Hospital in Liberec, Liberec, Husova 357/28, 46001 Liberec 1, Czech Republic \\ ${ }^{5}$ The Institute for Nanomaterials, Advanced Technologies and Innovation, Bendlova 1409/7, 46001 Liberec 1, \\ Czech Republic \\ ${ }^{6}$ Faculty of Textile Engineering, Technical University of Liberec, Studentska 1402/2, 46117 Liberec 1, Czech Republic
}

Received 13 January 2020; accepted in revised form 27 March 2020

\begin{abstract}
Nanofibrous materials have great potential for use in tissue engineering due to their structure, which mimics the extracellular fibrous matrix. Increasing their biological activity is currently the main goal in the development of these scaffolds. From the standpoint of promoting healing and tissue regeneration, the use of human platelets containing hundreds of biologically active molecules is promising. The present work deals with the preparation of PVA-based nanofibrous material containing native platelet-derived proteins that are released in a sustained manner. The needleless electrospinning process of preparation of material that does not affect the activity of incorporated proteins has been optimized, and the resulting material can be produced on a large scale with a protein loading efficiency of $0.64 \%$. The reasonable fiber diameter distribution $(370 \pm 150 \mathrm{~nm})$ with low defects ensures a homogeneous distribution of proteins. The use of high molecular weight PVA $(125000 \mathrm{~g} / \mathrm{mol})$ with a high degree of hydrolysis $(98-98.8 \%)$ resulted in a $40 \%$ reduction in PVA solubility without the need for subsequent covalent crosslinking. This, in turn, results in a sustained release of proteins, where after an initial burstrelease of $90 \%$ of the proteins, $10 \%$ is gradually released over the next 7 days. Our results demonstrate the potential use of the platelet-lysate loaded PVA material in tissue engineering.
\end{abstract}

Keywords: nanomaterials, PVA, electrospinning, platelets, growth factors

\section{Introduction}

Electrospun nanofibrous materials are being studied intensively for use in tissue engineering. The structure of these materials resembles natural extracellular matrix, has a high interconnected porosity and also a high surface-area to volume ratio. Thanks to these properties, these materials effectively support cell adhesion and proliferation by their structure and allow easy passage of substances (nutrient and waste)
$[1,2]$. Furthermore, these scaffolds appear to be very promising in terms of drug delivery that allow longterm and controlled drug release. It is essential to select the polymer and the encapsulation technique with respect to the application (target tissue) and the biologically active compound to be incorporated $[2,3]$. For the treatment of chronic wounds (e.g. patients with diabetes), immobilization of growth factors (GFs) appears to be a promising approach to promote 
healing [4-7]. In the case of the incorporation of native proteins, it is essential to influence their biological activity as little as possible. Related to this is the selection of a suitable solvent system, polymer, and electrospinning technique itself. It can be promising to use water-soluble polymers - such as natural hyaluronic acid [8], collagen [9], and gelatin [2] or synthetic PVA [10-12].

However, in order to ensure the gradual release of proteins from fibers made of water-soluble polymers, additional polymer crosslinking is generally necessary to slow down the dissolution of the material in an aqueous environment, which is necessary for a gradual release of the incorporated compound [2]. Typically, crosslinking requires a crosslinking agent [10, 13, 14], high temperature application [8], or application of UV-radiation [9]. However, these factors often negatively affect either the activity of the incorporated protein or cause the cytotoxicity of the material [2].

Poly(vinyl alcohol) (PVA) is a polymer for medical applications of interest due to its low cytotoxicity and good biocompatibility. It is a hydrophilic, semicrystalline polymer with good chemical resistance and the ability to form hydrogels. PVA is non-degradable under most physiological conditions $[15,16]$. PVA is derived from hydrolysis of poly(vinyl acetate) and is available in a wide variety of degrees of hydrolysis (88-99.8\%). As the degree of hydrolysis increases, the solubility of PVA in water decreases, and this property is further influenced by the molecular weight of the polymer [17]. This is due to physical cross-linking. Among PVA macromolecules, numerous interchain hydrogen bonds are formed between hydroxyl groups and Van der Waals interactions between the hydrocarbon polymer backbones [18]. Also, the materials prepared from PVA with high hydrolysis are less soluble in the aqueous environment. They are typically hydrogels [18], but this also applies to electrospun materials [17, 19-21].

Electrospinning is a process in which nanofibres are formed from a polymer solution due to high electrical voltage. The success of the process depends on a number of parameters, including selecting a polymer and the composition of the spinning solution (solvent system, polymer concentration). It is not easy to prepare a polymer solution having sufficient concentration for fiber formation from PVA with high hydrolysis and high molecular weight [17]. For this reason, the PVA nanofibres are typically electrospun from solutions containing the addition of surfactants, salts, adjusted $\mathrm{pH}$, optionally using ultrasound $[2,14,20$, 21]. However, these substances and processes can negatively affect the activity of incorporated biologically active molecules, as well as additional crosslinking $[9,10,12,22,23]$.

Although drug sustained release profiles are frequently reported through multifluid electrospinning [24], through polymer blank coating strategies [25], and through the applications of insoluble polymers [26], little attention has been paid to the possibility of directly using soluble polymers as filament-forming matrices. In the presented work, we describe largescale electrospinning of nanofibrous materials based on PVA with high hydrolysis, which contains native platelet growth factors. A solvent system containing only water and ethanol was used to prepare spinning solutions. Materials were electrospun using largescale continuous needleless electrospinning (Nanospider $^{\mathrm{TM}}$ technology). The resulting material contains homogeneously spread proteins that do not lose its biological activity. Due to the high molecular weight and hydrolysis of the used PVA, the slower release of proteins occurs without the need for additional polymer cross-linking.

\section{Materials and methods}

\subsection{Materials and protein solutions}

PVA130_88 (Sloviol R, $M_{\mathrm{w}} 130000 \mathrm{~g} / \mathrm{mol}$; $D H$ $88 \%$, Novácke chemické závody, Slovakia), PVA50_98 ( $M_{\mathrm{w}} 50-85000 \mathrm{~g} / \mathrm{mol} ;$ DH 98-98,9\%, Acros Organics, Belgium), PVA89_99 ( $M_{\mathrm{w}} 89$ 98000 g/mol; $D H$ 99+\%, Merck, Czech Republic), PVA125_98 (Mowiol20_98, $M_{\mathrm{w}} 125000 \mathrm{~g} / \mathrm{mol} ; D H$ 98\%, Merck, Czech Republic) and PVA130_99 $\left(M_{\mathrm{w}}\right.$ 130000 g/mol; $D H$ 99+\%; Merck, Czech Republic). The solvents used were distilled water and ethanol (Penta, Czech Republic). Platelet lysate (PL) was prepared from a thrombocyte rich solution (TRS, obtained from the regional hospital in Liberec, Czech Republic). The concentration of platelets in TRS was 700-900 $10^{6} \mathrm{PLT} / \mathrm{ml}$. Fresh TRS (1 day after donation) was frozen at $-80^{\circ} \mathrm{C}$, and the day before use was thawed at $4{ }^{\circ} \mathrm{C}$. The resulting suspension was centrifuged $\left(2800 \cdot \mathrm{g}, 4^{\circ} \mathrm{C}, 30 \mathrm{~min}\right)$, and the resulting supernatant (PL) was collected and stored at $4{ }^{\circ} \mathrm{C}$ until use. The horseradish peroxidase (HRP) solution was prepared immediately before use dissolving $10 \mathrm{mg}$ of HRP (Merck, Czech Republic) in $1 \mathrm{ml}$ of acetate buffer (0.2 M, pH 6). 


\subsection{Preparation of spinning solutions}

Spinning solutions of PVA $(6-13 \%(\mathrm{w} / \mathrm{w}))$ were prepared with respect to the used PVA. An appropriate amount of polymer was added to the premixed solvent (water:ethanol) and stirred at $90{ }^{\circ} \mathrm{C}$ until the polymer was completely dissolved. Subsequently, solutions were gradually cooled to room temperature while stirring. Platelet lysate (PL) tempered to room temperature was added to the prepared PVA solution, stirred for $30 \mathrm{~min}$ and subsequently spun. 10\% PVA130_88 and PVA125_98 solutions were prepared by dissolving $10 \mathrm{~g}$ of PVA in $90 \mathrm{~g}$ of solvent (water: ethanol $(8: 2 ; \mathrm{w} / \mathrm{w})$ ). Solutions containing $10 \%$ of PL were prepared by dissolving $10 \mathrm{~g}$ of PVA in $80 \mathrm{~g}$ of solvent, and then $10 \mathrm{~g}$ of PL was added. The solution containing HRP was prepared by dissolving $10 \mathrm{~g}$ of PVA in $80 \mathrm{~g}$ of solvent, and then $10 \mathrm{~g}$ of HRP solution was added.

\subsection{Nanofibrous materials preparation}

Materials were prepared from PVA solutions using electrospinning technology (Nanospider ${ }^{\mathrm{TM}}$ 1WS500U, Elmarco, Czech Republic). Prepared polymer solutions were electrospun at humidity $25 \%$ and temperature $32^{\circ} \mathrm{C}$. The applied voltages of -10 and $+60 \mathrm{kV}$ were used in the collector and the string, respectively. The electrode (string) distance from the collector was $145-160 \mathrm{~mm}$, EMW speed was $250 \mathrm{~mm} / \mathrm{sec}$, and rewinding speed $8 \mathrm{~mm} / \mathrm{min}$. Prepared materials were stored at $4{ }^{\circ} \mathrm{C}$.

\subsection{Morphological analysis}

Morphological analysis was performed by scanning electron microscopy (Vega Tescan 3, Tescan, Czech Republic) after $7 \mathrm{~nm}$ of gold sputter coating (Quorum Q50ES, Quorum Technologies, Great Britain). Samples were analyzed at an accelerating voltage of
$10 \mathrm{kV}$. The average diameter and the diameter distribution were evaluated using NIS Elements (100 randomly measured value per each material).

\subsection{Protein content analysis}

For protein content, $10 \mathrm{mg}$ pieces of prepared PVA130_88 materials were placed into $1 \mathrm{ml}$ in phosphate-buffered saline (PBS, $\mathrm{pH}$ 7.4) and dissolved. The solution was then analyzed by sodium dodecyl sulfate-polyacrylamide gel electrophoresis (SDSPAGE). $10 \mu 1$ of each sample were diluted (1:1) in a loading buffer ( $0.15 \mathrm{M}$ Tris. $\mathrm{HCl}, \mathrm{pH} 6.8,30 \%$ glycerol (v/v)), 15\% $\beta$-mercaptoethanol (v/v), 1\% SDS $(\mathrm{w} / \mathrm{v}), 0.01 \%$ bromophenol blue (w/v)). $20 \mu \mathrm{l}$ of the prepared samples were run using $8 \%$ gel $(2 \mathrm{~h}, 90 \mathrm{~V})$ with a wide-range molecular weight marker (Protein wide range MW Marker, Amresco). Subsequently, gels were silver stained. First, the gel was placed for an hour in $100 \mathrm{ml}$ of fixing solution (50 ml ethanol, $12 \mathrm{ml}$ acetic acid, $50 \mu \mathrm{l}$ formaldehyde (37\%), and $38 \mathrm{ml}$ of distilled water, all chemicals purchased from Penta, Czech Republic). Next, the gel was washed in $50 \%(\mathrm{w} / \mathrm{w})$ ethanol for $3 \times 20$ minutes. Subsequently, the gel was placed in a solution of $0.63 \mathrm{mM}$ sodium thiosulfate pentahydrate (Lachema Neratovice, Czech Republic) for 1 minute. Next, the gel was rinsed with distilled water for 3'20 seconds. After washing, the gel was placed in a staining solution (6 mM silver nitrate, Merck, Czech Republic) for 30 minutes. It was then washed again with distilled water and placed in a $100 \mathrm{ml}$ of developing ( $3 \mathrm{~g}$ of sodium carbonate (Merck, Czech Republic), $2 \mathrm{ml}$ of $0.63 \mathrm{mM}$ sodium thiosulfate pentahydrate, $50 \mu 1$ of formaldehyde, $98 \mathrm{ml}$ of distilled water) for 10-60 minutes until gel staining. After that, the gel was placed in a stopping solution $(25 \mathrm{mM}$ EDTA (Merck, Czech Republic)) for 20 minutes.

Table 1. Composition of spinning solutions used for the preparation of reported PVA materials: PVA concentration (in spinning solutions), molecular weight, degree of hydrolysis, solvents ratios, and PL concentration.

\begin{tabular}{|l|c|c|c|c|c|}
\hline \multicolumn{1}{|c|}{ PVA } & $\begin{array}{c}\text { Concentration, w/w } \\
{[\mathbf{\%}]}\end{array}$ & $\begin{array}{c}\boldsymbol{M}_{\mathbf{w}} \\
{[\mathbf{g} / \mathbf{m o l}]}\end{array}$ & $\begin{array}{c}\boldsymbol{D H} \\
{[\mathbf{\%}]}\end{array}$ & $\begin{array}{c}\text { Solvent ratio } \\
{[\text { water:ethanol] }}\end{array}$ & $\begin{array}{c}\text { PL concentration, w/w } \\
{[\%]}\end{array}$ \\
\hline PVA130_88 & 12 & 130000 & 88 & $8: 2$ & 0 \\
\hline PVA130_88_7.5\% PL & 12 & 130000 & 88 & $8: 2$ & 10 \\
\hline PVA130_88_10\% PL & 12 & 130000 & 88 & $8: 2$ & 12.5 \\
\hline PVA130_88_12.5\% PL & 12 & 130000 & 88 & $8: 2$ & 0 \\
\hline PVA50_98 & 12 & $50-85000$ & $98-98.9$ & $8: 2$ & 0 \\
\hline PVA89_99 & 10 & $89-98000$ & $99+$ & $8: 2$ & 10 \\
\hline PVA125_98 & 10 & 125000 & $98-98.9$ & $8: 2$ & 0 \\
\hline PVA125_98_10\% PL & 10 & 125000 & $98-98.9$ & $8: 2$ & $8: 2$ \\
\hline PVA130_99 & 6 & 130000 & $99+$ & & 0 \\
\hline
\end{tabular}


For the protein release analysis, $10 \mathrm{mg}$ of PVA125 98 materials were placed into $1 \mathrm{ml}$ of phosphatebuffered saline (PBS, pH 7.4) and incubated at $37^{\circ} \mathrm{C}$. Proteins released into buffer were analyzed after 1 , 2, 4, 8, $24 \mathrm{~h}, 3$, and 7 days. $200 \mu 1$ of the solution was withdrawn for analysis, and $200 \mathrm{ml}$ of pure buffer was added. Protein concentration in withdrawn samples was measured using the Bradford method [27] and chromatography. For the Bradford method, a $5 \mu \mathrm{l}$ of the sample was added into $250 \mu \mathrm{l}$ of Bradford reagent (Merck, Czech Republic) in a 96 well plate. The absorbance was measured after $5 \mathrm{~min}$ incubation at $R T$ at $595 \mathrm{~nm}$. Bovine serum albumin (BSA, Merck, Czech Republic) was used as the standard.

Protein loading capacity was determined using Equation (1):

$$
\begin{aligned}
& \text { Loading capacity }\left[\mathrm{mg} \cdot \mathrm{g}^{-1}\right]= \\
& =\frac{\text { amount of protein in fibers }}{\text { total mass of fibers }}
\end{aligned}
$$

\subsection{Protein activity analysis}

For protein activity analysis, we used horseradish peroxidase enzyme assay [28]. $1 \mathrm{mg}$ pieces of prepared PVA130_88 incorporated with HRP were placed into $1 \mathrm{ml}$ of acetate buffer and dissolved at room temperature $(5 \mathrm{~min})$. The samples for analysis were diluted 5 times. A $10 \mu 1$ of diluted samples were added into $190 \mu 1$ of HRP Master Mix (180 $\mu 1$ of acetate buffer, $8 \mu 1 \mathrm{H}_{2} \mathrm{O}_{2}, 2 \mu \mathrm{l} \mathrm{TMB}$ ) and to stop the reaction $50 \mu \mathrm{HCl}$ was added after $20 \mathrm{sec}$. After stopping, the absorbance of yellow-colored samples was measured at $450 \mathrm{~nm}$. HRP content was measured by spectrophotometry using the Bradford method. The activity of HRP was calculated as specific activity (U/mg protein) and was expressed as a percentage of control. The enzyme activity in samples was measured on day 0 , then after $1,3,7,14$, and 21 days. The samples were stored at $4{ }^{\circ} \mathrm{C}$.

\subsection{Chromatography (protein and PVA content analysis)}

For the chromatography analysis, $200 \mu 1$ of the samples were diluted in $1 \mathrm{ml}$ of a solution of $100 \mathrm{mM}$ $\mathrm{NaH}_{2} \mathrm{PO}_{4}$ (pH 6.8), $100 \mathrm{mM} \mathrm{NaCl}$ and $0.03 \%$ (w/v) $\mathrm{NaN}_{3}$. The same solution was used as the mobile phase during the analysis. A Dionex Ultimate 3000 HPLC system with an Ultimate 3000 diode array detector and an Agilent 1260 Infinity II GPC/SEC
MDS light scattering detector was used. The column used was Superdex 200 Increase (GE Healthcare) with a length of $300 \mathrm{~mm}$ and an internal diameter of $3.2 \mathrm{~mm}$. The mobile phase was firstly filtered through a $0.1 \mu \mathrm{m}$ pore size PTFE membrane filter (Advantec) and then through an Anodisc inorganic filter membrane with a pore size of $0.02 \mu \mathrm{m}$ (Whatman) to remove as many solid particles as possible. The flow rate was $0.12 \mathrm{ml} / \mathrm{min}$, and the chromatograms were recorded for $25.6 \mathrm{~min}$. The measurements were performed at room temperature. Chromatograms were recorded at $210,225,255$, and $279 \mathrm{~nm}$ wavelength and at 90 and $15^{\circ}$ angle by the light scattering detector. The samples were filtered through $13 \mathrm{mM}$ diameter $0.45 \mu \mathrm{m}$ pore size nylon syringe filters (Chromservis Filterpure), $20 \mu 1$ of the sample was injected by the autosampler.

\subsection{Infrared spectroscopy (FT-IR)}

The chemical composition of materials was investigated using a Fourier transform spectrometer (Nicolet iZ10; Thermo Fisher, USA) at room temperature. Samples were placed on the ATR diamond crystal for analysis, and spectrum analysis was performed in the infrared region in the range of $400-4000 \mathrm{~cm}^{-1}$ and spectral resolution of $4 \mathrm{~cm}^{-1}$.

\section{Results and discussion}

In the presented work, concerning the preparation of the PVA nanofibrous layer containing native proteins, the optimum composition of the spinning solution (PVA concentration, platelet lysate concentration, solvent system) was firstly sought, and the effect of spinning on the activity of incorporated proteins was studied. Subsequently, in order to slow the dissolution of the material, a suitable PVA with higher hydrolysis was sought, the spinning conditions were optimized, and the homogeneity of the incorporated proteins and their release was evaluated. The resulting material is a slowly soluble PVA nanofibrous layer containing homogeneously spread active platelet growth factors.

\subsection{Preparation of the nanofibrous membrane with immobilized proteins}

In the first phase of the material development, the large scale electrospinning of proteins was tested. We used PVA with a molecular weight of $130000 \mathrm{~g} / \mathrm{mol}$ and a degree of hydrolysis of $88 \%$ (PVA130_88). The polymer concentration in the spinning solutions 

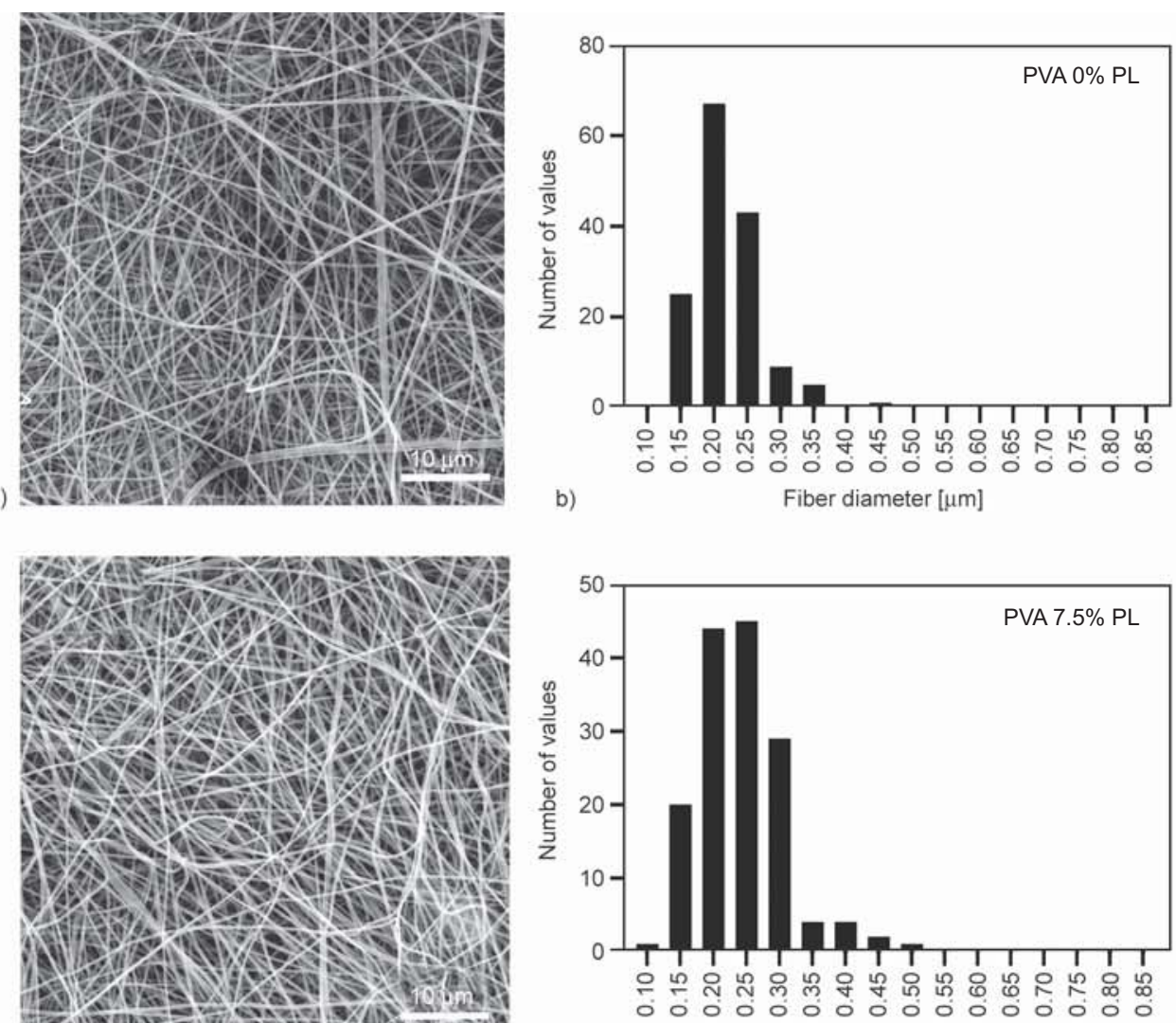

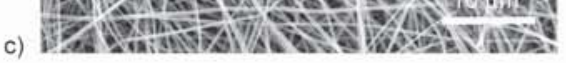
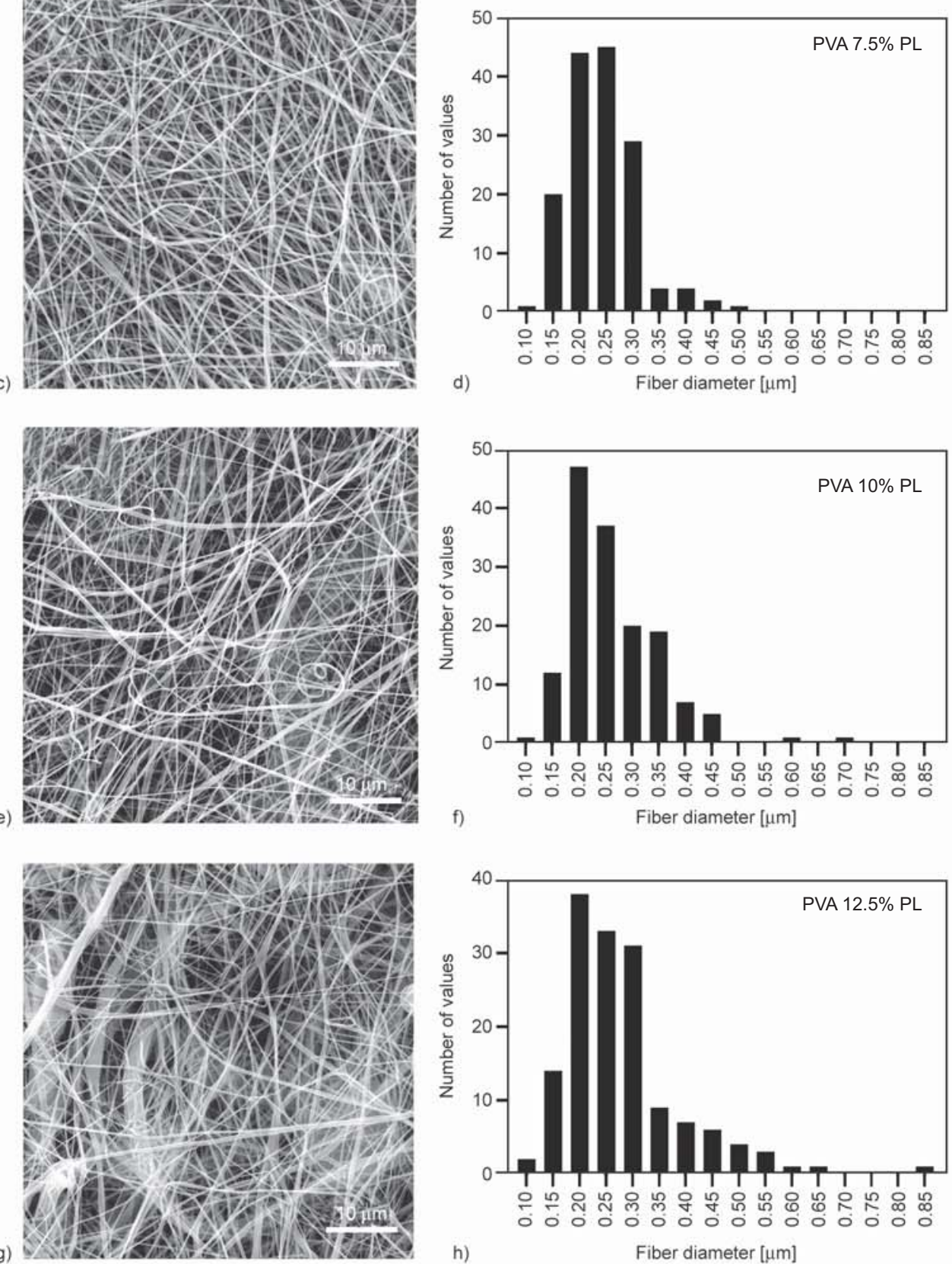

$12 \%$ (w/w) PVA

$M_{\mathrm{w}} 130000$

DH $88 \%$

Average fiber diameter $(0.21 \pm 0.05) \mu \mathrm{m}$

\section{$12 \%(w / w) P V A+7.5 \% P L$ $M_{\mathrm{w}} 130000$} DH $88 \%$

Average fiber diameter $(0.25 \pm 0.09) \mu \mathrm{m}$

$12 \%(w / w) P V A+10 \% P L$ $M_{\mathrm{w}} 130000$ DH 88\%

Average fiber diameter $(0.28 \pm 0.12) \mu \mathrm{m}$

$12 \%(w / w) P V A+12.5 \% P L$ $M_{\mathrm{w}} 130000$ DH 88\%

Average fiber diameter $(0.29 \pm 0.12) \mu \mathrm{m}$

Figure 1. SEM pictures and fiber diameter distribution histograms of materials with different content of PL in spinning solution: pure PVA $(\mathrm{a}, \mathrm{b}) ; 7.5 \%$ of PL (c, d); $10 \%$ of PL (e, f) and $12.5 \%$ of PL (g, h). Magnification of SEM pictures $5000 \times \mathrm{x}$, scale bar $10 \mu \mathrm{m}$. 
was $12 \%(\mathrm{w} / \mathrm{w})$. The solvent system contained $8: 2$ water and ethanol $(\mathrm{w} / \mathrm{w})$. The spinning solutions contained $7.5,10$, and $12,5 \%$ of platelet lysate $(\mathrm{w} / \mathrm{w}$; added instead of the aqueous portion of the solvent system). For spinning of solutions with platelets, the spinning conditions had to be adjusted - polymer feed rate (cartridge speed reduced from $205 \mathrm{~mm} / \mathrm{s}$ to $156 \mathrm{~mm} / \mathrm{s}$ ) and voltage (voltage increased from $+40.5 /-19.5$ to $+46.6 /-19.5 \mathrm{kV}$ for 7.5 and $10 \%$ PL and up to $+51 /-19.5 \mathrm{kV}$ for $12.5 \% \mathrm{PL})$. Morphological analysis of electrospun layers (Figure 1) showed that the addition of PL affects the resulting morphology of the fibers very little. In the case of $12.5 \%$ PL solution, the fiber morphology was still comparable; however, the presence of defects was increasing (Figure $1 \mathrm{~g}$ ), and even macroscopically, the layer contained more significant defects. The fiber diameter was then comparable for all layers but increased slightly with increasing protein content $(0.21 \pm 0.05 \mu \mathrm{m}$ for pure PVA, up to $0.29 \pm 0.12 \mu \mathrm{m}$ for PVA containing $12,5 \%$ PL). Compared to similarly electrospun protein-containing PVA materials [14, 22], it is apparent that the addition of proteins always results in an increase in fiber diameter and subsequent defect formation.

\subsection{Protein loading efficiency and protein activity}

Since the materials prepared from PVA130_88 (Mowiol 18-88) were completely dissolved in water immediately, it was possible to determine the total content of incorporated proteins. All layers were analyzed for protein content by SDS-PAGE, spectrophotometry and chromatography. The results from these analyses show, that with increasing PL content in the spinning solution, the protein content in electrospun material increases accordingly (Figure 2b). The amount of protein per gram of the final layer was $3.56 \mathrm{mg}$ of protein for $7.5 \% \mathrm{PL} ; 6.42 \mathrm{mg}$ protein for $10 \% \mathrm{PL}$ and $7.54 \mathrm{mg}$ protein for $12.5 \% \mathrm{PL}$.

For a material prepared from a $10 \%$ PL solution, the protein loading efficiency was $0.64 \%(\mathrm{w} / \mathrm{w})$. Porto et al. [22] describe the efficiency of incorporated $\alpha$ amylase up to $5.2 \%(52.1 \mathrm{mg} / \mathrm{g})$ and $\mathrm{Wu}$ et al. [14] the efficiency of incorporation of cellulase into PVA up to $11.4 \%(114 \mathrm{mg} / \mathrm{g})$. In the case of incorporation of growth factors, protein loading efficiency is generally much lower. Yang et al. [7] prepared bFGF containing $80 \mu \mathrm{g} / \mathrm{g}(0.008 \%)$ and Zhao et al. [29] reported loading efficiency of bFGF $0.72 \cdot 10^{-3} \%$ $(7.2 \mu \mathrm{g} / \mathrm{g})$ in prepared materials. The differences in loading are mainly due to the composition of the spinning solutions and also the technology used. For enzymes, a high concentration of enzyme in the spinning solution (up to 10 weight percent [14]) was generally used, while very low amounts were used for growth factors. Another factor is the spinning method used - in the case of enzymes, proteins were added directly to the spinning solution, while the materials carrying growth factors were prepared using coaxial electrospinning [7] or electrospinning from protein emulsion [29]. Compared to the usual efficiency of incorporation of growth factors, the loading achieved by us $(0.64 \%)$ is remarkable, although it reaches only a tenth part reported for maximum enzyme loading. However, it should be noted that platelet lysate contains a number of other proteins besides growth factors, and therefore the actual content of growth factors will be lower [30]. The limiting
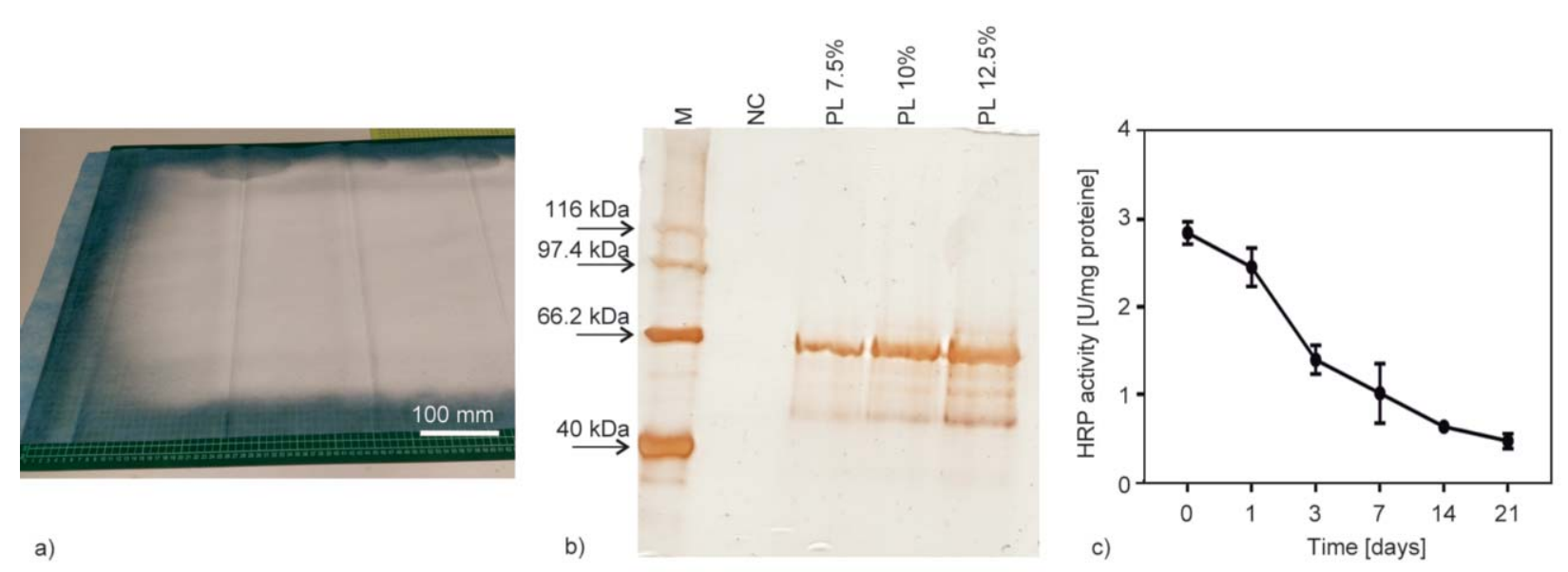

Figure 2. Picture of nanofiber layer (a), 12\% SDS-PAGE of protein content in electrospun PVA_PL materials: $40 \mathrm{mg}$ of PVA_PL material dissolved in $1 \mathrm{ml}$, sample volume $10 \mu \mathrm{l}(\mathrm{b})$. The relative activity of HRP [\%] in electrospun material: after electrospinning (0 days) and during the following 21 days (c). 
factor is mainly the source of proteins - platelet lysate. We are not able to increase the lysate content in the spinning solution (without causing defects); however, it would be possible, for example, to increase the protein concentration in the platelet lysate and thereby achieve even greater loading efficiency [31]. The advantage of using a platelet lysate is that it is a physiological combination of growth factors and other proteins [32], and compared to recombinant growth factors, the platelet lysate is readily available, and the purchase price of the material (PL) is low.

Model HRP protein was used to determine the effect of the electrospinning process on protein activity. HRP was incorporated into PVA at $1 \mathrm{mg}$ HRP per $1 \mathrm{~g}$ of PVA. Spinning solution and electrospinning was performed in the same manner as electrospinning of platelet lysates. To measure the activity, the samples were dissolved in water, and HRP activity was subsequently measured. From the measured data, it was found that the activity of HRP is not negatively influenced by the spinning process. Compared to the HRP control solution with an activity of $0.1 \pm 0.0037 \mathrm{U} / \mathrm{ml}$, an HRP activity of $0.0963 \pm 0.0095 \mathrm{U} / \mathrm{ml}$ was determined for a $1 \mathrm{mg}$ of sample dissolved in $1 \mathrm{ml}$ of buffer. This corresponds to a loss of activity of less than $4 \%$. Samples were stored at $4{ }^{\circ} \mathrm{C}$ after spinning, and HRP activity was tested over the next 3 weeks (Figure 2c). The results show that due to storage, HRP activity decreases in 3 weeks to $20 \%$ of its original activity. MorenoCortez et al. [33] showed a similar trend of decreasing activity in the case of papain immobilized into PVA fibers crosslinked by glutaraldehyde.

\subsection{Reducing solubility of the material}

Covalent modifications are generally used to reduce the solubility of PVA, including chemical crosslinking of electrospun PVA [8-10, 13, 14] or additional modification of PVA OH groups [34]. However, these processes often negatively affect either the activity of the incorporated protein or cause the cytotoxicity of the material. On the other hand, there is also the possibility to reduce PVA water solubility by strengthening of physical crosslinking between $\mathrm{OH}$ groups of PVA chains. Materials prepared from PVA with a high degree of hydrolysis $(98+)$ have reduced water solubility naturally due to the physical crosslinking of PVA chains [18]. For the above reasons, we have attempted to prepare a material where the proteins are immobilized into PVA with a high degree of hydrolysis. However, it is necessary to find PVA with appropriate molecular weight and degree of hydrolysis in order to maintain its spin-ability.

With regard to the results already published $[17,19-$ 21], we tested PVA with the hydrolysis of $98 \%$ and higher with molecular weights of $50000 \mathrm{~g} / \mathrm{mol}$ and higher. The effect of solution concentration and solvent system composition on fiber formation was studied. In order to reduce the surface tension $[17,20,21]$ the ethanol was added to the spinning solution. Nanospider technology utilizes continuous needleless spinning from the polymer level, and if the solvent is pure water, the productivity of the process is very low. The addition of ethanol up to $20 \%(\mathrm{w} / \mathrm{w})$ does not affect the activity of the incorporated proteins (see model protein results), but significantly improves the process.

In these experiments, the aim was to find PVA with the highest molecular weight, and degree of hydrolysis that could be electrospun (on a large scale), and the resulting layer would be a homogeneous nanofiber layer with a narrow fiber diameter distribution and low occurrence of defects. The electrostatic spinning of the solutions took place under the following conditions - voltage $-10 / 60 \mathrm{kV}$, electrode distance $159-165 \mathrm{~mm}$, rewinding speed $8 \mathrm{~mm} / \mathrm{min}$, cartridge speed $200-250 \mathrm{~mm} / \mathrm{sec}$, temperature $32^{\circ} \mathrm{C}$ and $25 \%$ relative humidity. A cartridge with different holes was chosen to dispense the polymer solution to the electrode (a string with diameter $0.4 \mathrm{~mm}$ ). $0.6 \mathrm{~mm}$ holes are sufficient for PVA with $M_{\mathrm{w}} 50-85000 \mathrm{~g} / \mathrm{mol}$, $0.7 \mathrm{~mm}$ is required for $M$ w $89-98000 \mathrm{~g} / \mathrm{mol}$, and $0.8 \mathrm{~mm}$ is required for the highest $M w 125000$ and $130000 \mathrm{~g} / \mathrm{mol}$. For each PVA, there is a minimum polymer concentration required for fiber formation and a maximum concentration at which the solution can be electrospun [17]. With increasing molecular weight and degree of hydrolysis, the solubility of the PVA is reduced, and it is necessary to reduce the polymer concentration in the spinning solution (e.g. in the case of PVA130_99 to 6\% (w/w); Figure $3 \mathrm{~g}$, $3 \mathrm{~h})$. On the other hand, if the polymer concentration is too low, fiber formation cannot occur, and droplets are formed instead (i.e, electrospraying, Figure 3c, 3d) [20]. For the PVA used with a degree of hydrolysis of $99+$, it was possible to prepare spinning solutions with a polymer concentration well below $10 \%(\mathrm{w} / \mathrm{w})$, but it did not form a macroscopically homogeneous layer, and numerous defects were 

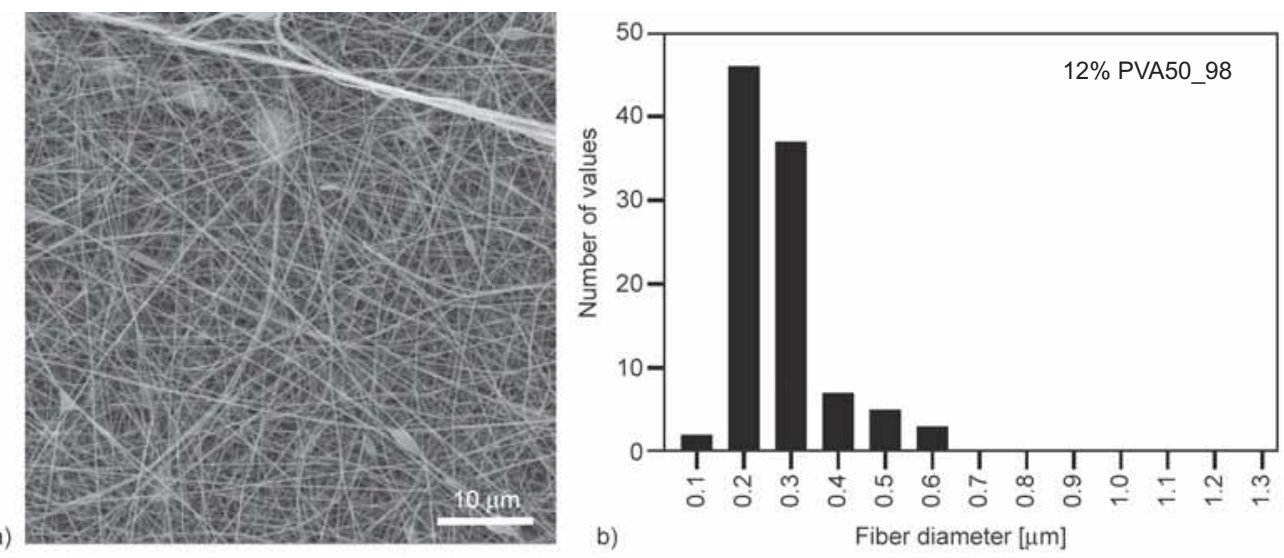

12\% (w/w) PVA50_98

$M_{\mathrm{w}}$ 50000-85000

DH 98-98.9\%

Average fiber diameter

$(0.27 \pm 0.10) \mu \mathrm{m}$
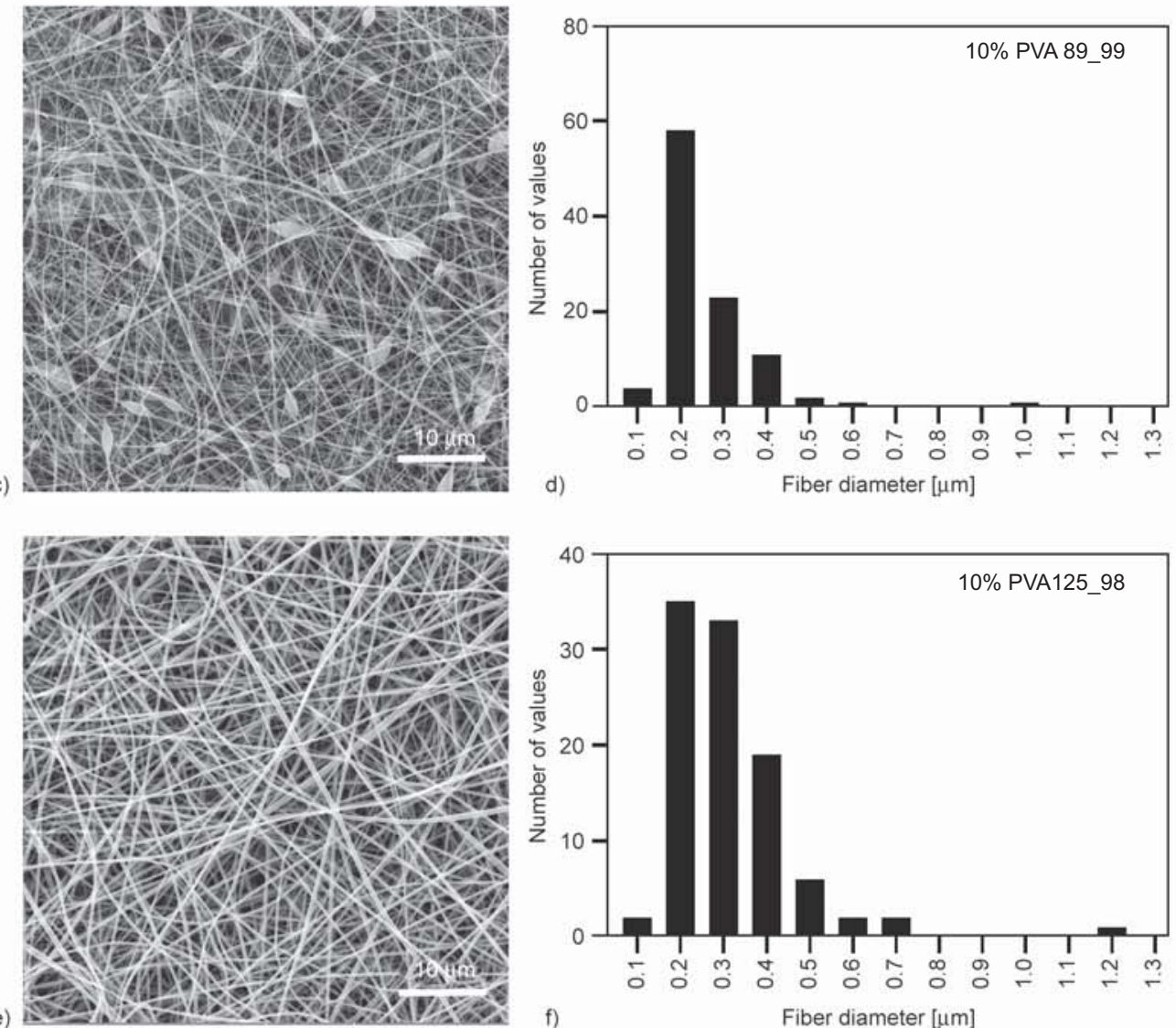

e)

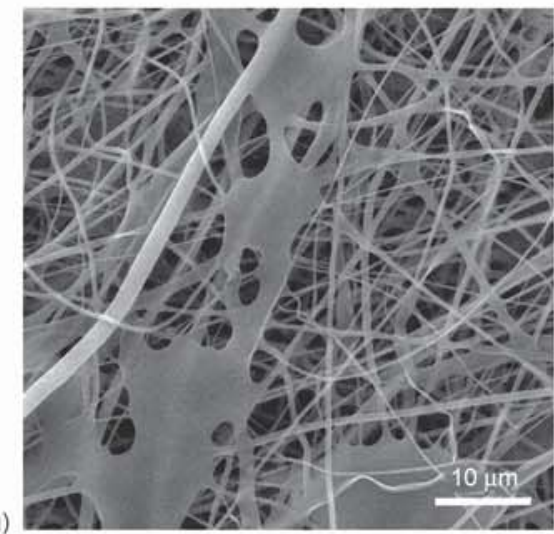

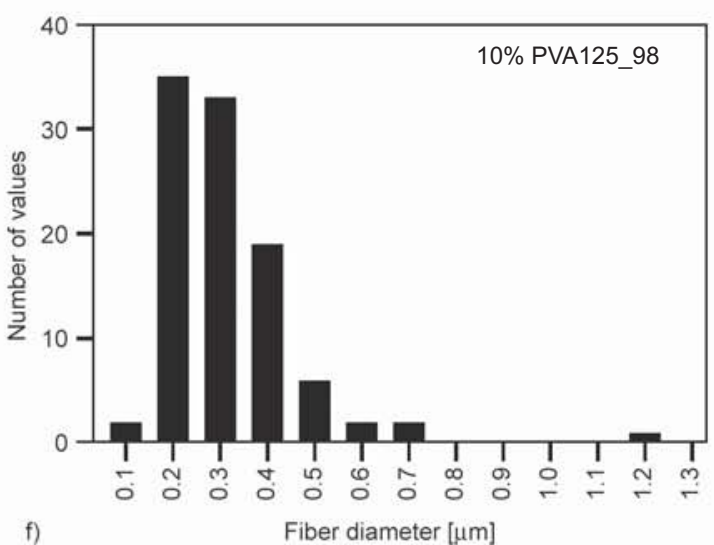

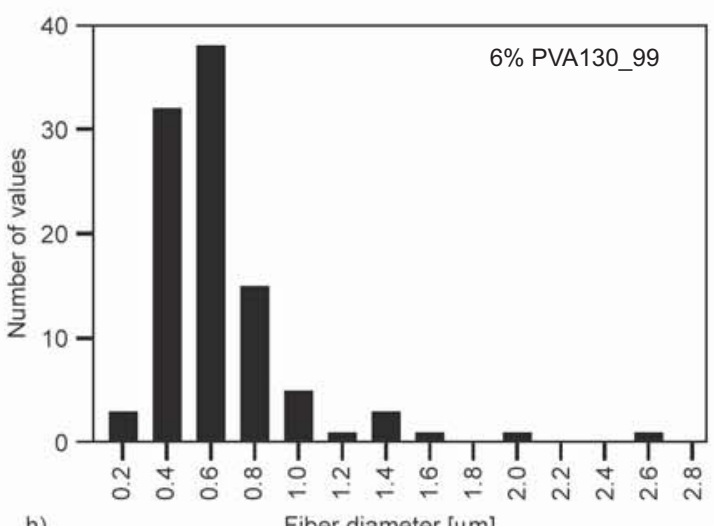

10\% (w/w) PVA89_99 $M_{\mathrm{w}}$ 89-98000 DH $99+\%$

Average fiber diameter $(0.25 \pm 0.11) \mu \mathrm{m}$

$10 \%$ (w/w) PVA125 98

$M_{\mathrm{w}} 125000$

DH $988-98.9 \%$

Average fiber diameter $(0.33 \pm 0.10) \mu \mathrm{m}$

$6 \%$ (w/w) PVA130_99 $M_{\mathrm{w}} 130000$ $99+88 \%$

Average fiber diameter $(0.64 \pm 0.36) \mu \mathrm{m}$

Fiber diameter [um]

Figure 3. SEM pictures and fiber diameter distribution histograms of materials prepared from PVA of different molecular weights and degree of hydrolysis: pure PVA50_98 (a, b); PVA89_99 (c, d); PVA125_98 (e, f) and PVA130_99 (g, h). Magnification 5000×, scale bar $10 \mu \mathrm{m}$. Magnification of SEM pictures 5000×, scale bar $10 \mu \mathrm{m}$. 
apparent (Figure 3g, 3h). It should also be noted that the polymer solution of PVA130_99 produced a physical gel [18] in the cartridge, which negatively affects the electrospinning process. Selected PVAs with a degree of hydrolysis of $98-99 \%$ were spinnable from $10 \%(\mathrm{w} / \mathrm{w})$ or higher concentration without significant defect formation. For PVA with a molecular weight below $100000 \mathrm{~g} / \mathrm{mol}$, a suitable polymer concentration is $12 \% .12 \%(\mathrm{w} / \mathrm{w})$ PVA50_98 produced smooth layers without major defects. $10 \%(\mathrm{w} / \mathrm{w})$ PVA89_99 also produced smooth layers with a minimum of defects, but morphology monitoring (beads/ droplets on fibers, Figure 3c, 3d) indicated that increasing the concentration of the solution was appropriate [20]. PVA125 98 was electrospun from $10 \%(\mathrm{w} / \mathrm{w})$ solution and formed a smooth layer, without major defects. The fiber diameters of the produced materials PVA50_98, PVA89_99, and PVA125_98 are almost comparable, and also the distribution of the fiber diameters is similar (Figure 3). Among the tested polymers, PVA125_98 was selected as the most suitable for incorporation of proteins, i.e. PVA with a molecular weight of $125000 \mathrm{~g} / \mathrm{mol}$ and a degree of hydrolysis of $98-98.8 \%$. This PVA can be electrospun from a $10 \%$ polymer solution, and the resulting layer is a homogeneous nanofibrous layer consisting of fibers with a narrow fiber diameter distribution (Figure 3e, 3f), which is essential to ensure a homogeneous loading of the incorporated substance [2].

\subsection{Material with reduced PVA solubility}

Based on the above results, we prepared material from PVA with molecular weight $125000 \mathrm{~g} / \mathrm{mol}$ and a degree of hydrolysis of 98-98.8\% (PVA125_98) containing platelet lysate. The spinning solution was composed of $10 \%$ PVA (w/w) and $10 \%$ PL (w/w). First, a solution containing only PVA was prepared - the polymer was slowly dissolved at $90^{\circ} \mathrm{C}$ and then slowly cooled to room temperature while stirring. The platelet lysate (tempered to room temperature) was then added to the PVA pre-solution. After thorough mixing, the solution was electrospun immediately. Prepared materials were homogeneous nanofibrous layers (Figure 2a) with similar fiber diameter (evaluated from five independent sets of materials)
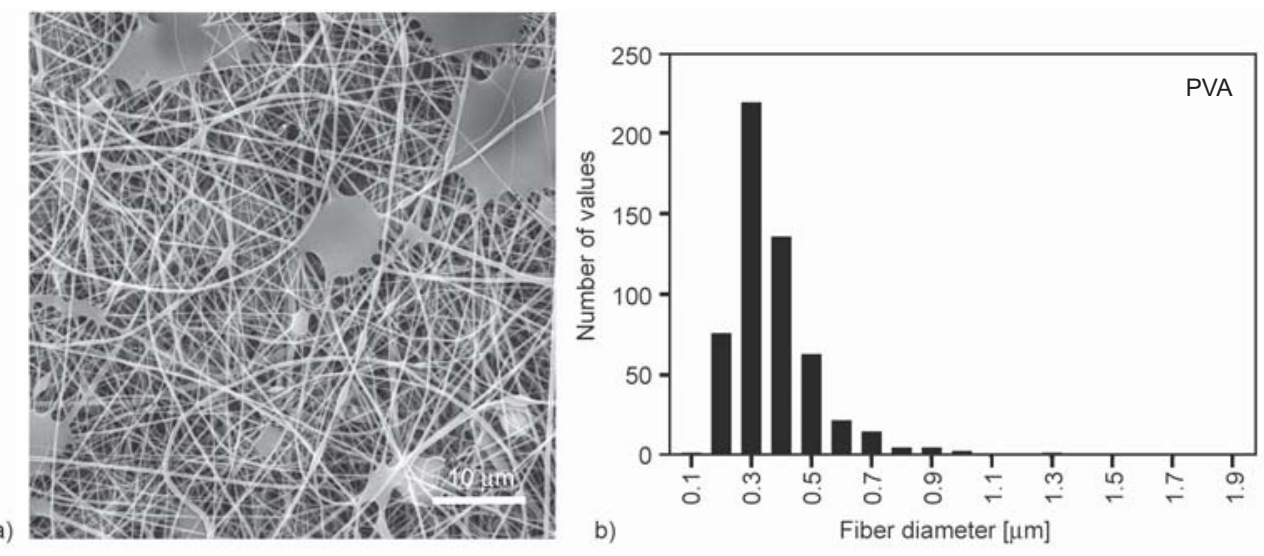

$10 \%(w / w)$ PVA125_98

$M_{\mathrm{w}} 125000$

DH $98-98.9 \%$

Average fiber diameter $(0.38 \pm 0.17) \mu \mathrm{m}$
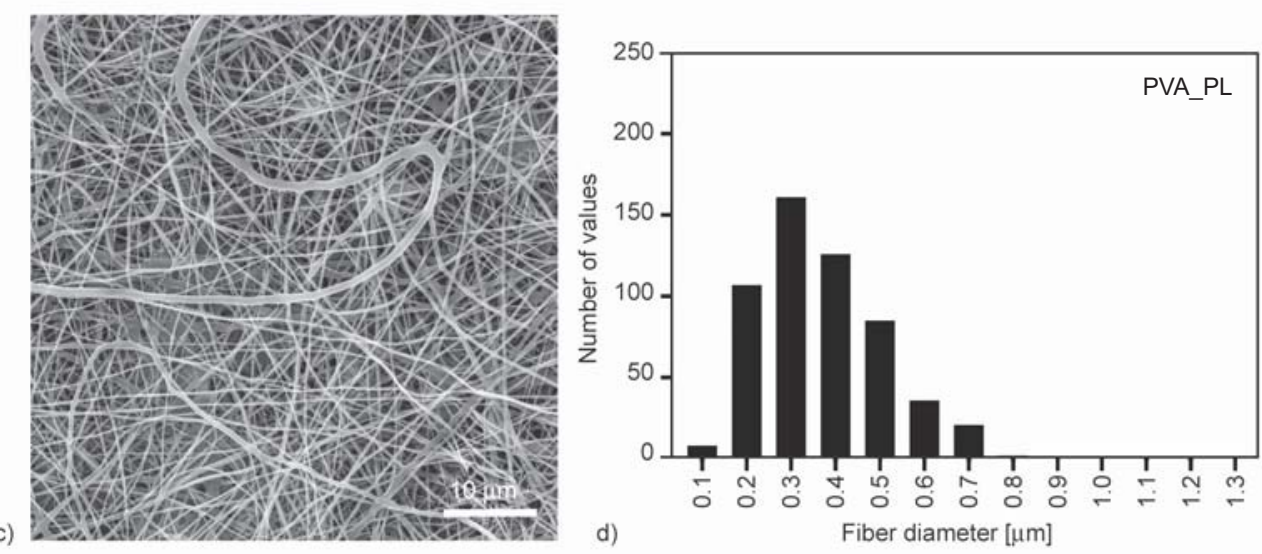

$10 \%(w / w)$ PVA125_98 +

$+10 \% \mathrm{PL}$

$M_{\mathrm{w}} 125000$

DH $98-98.9 \%$

Average fiber diameter $(0.37 \pm 0.15) \mu \mathrm{m}$

Figure 4. SEM images and fiber diameter distribution histograms of materials prepared from $10 \%$ PVA $\left(M_{\mathrm{w}} 125000 \mathrm{~g} / \mathrm{mol}\right.$, 98\% hydrolysis) with platelet lysate (c, d; PVA_PL) and without platelet lysate (a,b; PVA); magnification 5000×, scale bar $10 \mu \mathrm{m}$. 
(Figure 4). PVA materials with a protein content have an average fiber diameter of $370 \pm 150 \mathrm{~nm}$, and materials from pure PVA have an average fiber diameter of $376 \pm 170 \mathrm{~nm}$. The protein content does not affect the fiber diameter of the resulting materials. However, process productivity is affected significantly. The rate of fiber formation from the proteincontaining solution is higher than that of pure PVA. The needleless electrospinning technology used in the case of PVA enables the production of homogeneous nanofibrous materials on a large scale, even with incorporated native proteins. The advantage of the method used is its simplicity, e.g. compared to coaxial electrospinning or multiple-fluid electrospinning technologies [24], which are more complex; however, it can be difficult to scale up production of fibers. In addition, the process has been set up in such a way that the use of secondary polymers and other substances facilitating the spinning process of PVA
[35] is not necessary (with the exception of ethanol, which completely evaporates during electrospinning).

\subsubsection{The homogeneity of protein incorporation}

The homogeneity of protein incorporation was monitored by incorporating fluorescently labeled BSA. The results of the subsequent fluorescence microscopy (Figure 5) show that the proteins are distributed homogeneously within the material, but aggregates (clusters) are evident. However, when compared to the pictures from electron microscopy (Figure 4), no defects corresponding to these clusters are evident compared to the negative control (pure PVA). Observed aggregates are, therefore, probably located inside the fibers.

The chemical composition of prepared materials and homogeneity of protein distribution within the prepared layers was further evaluated by FTIR analysis (Figure 6a). The PVA spectrum presented

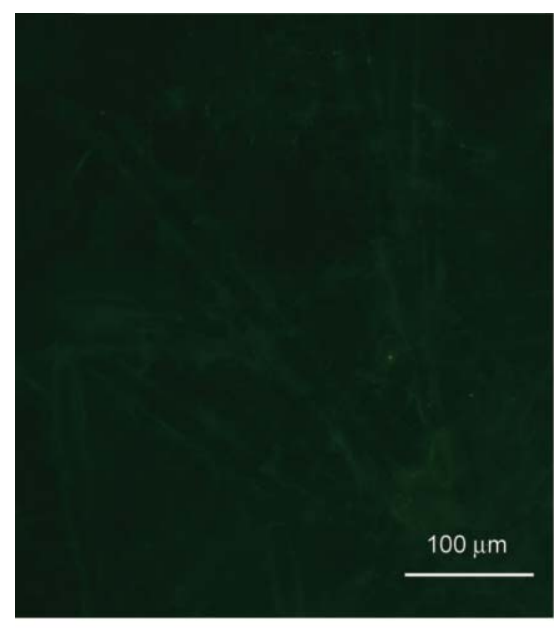

a)

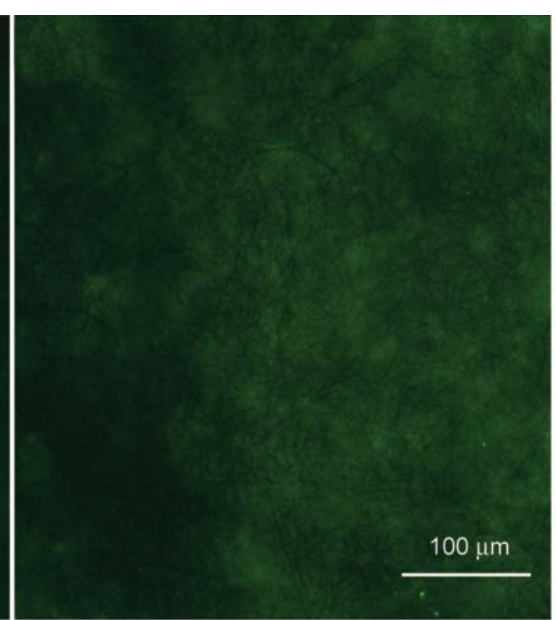

b)

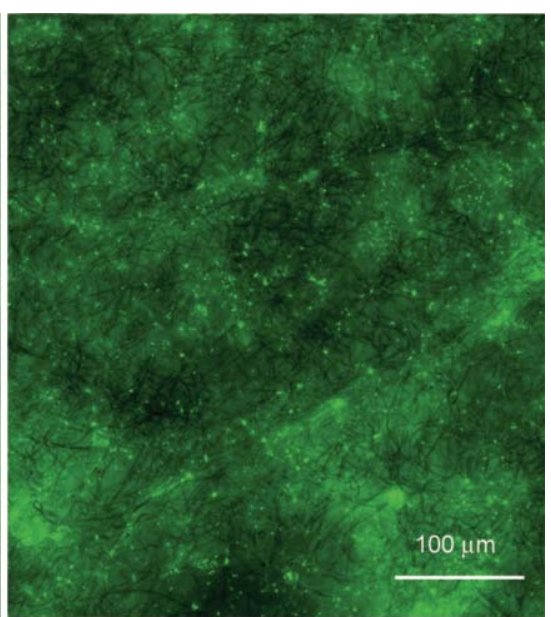

c)

Figure 5. Pictures from fluorescence microscopy of materials: pure PVA (a), PVA with incorporated PL (b), and PVA with PL together with BSA-FITC (c); magnification 200×, scale bar $100 \mu \mathrm{m}$.
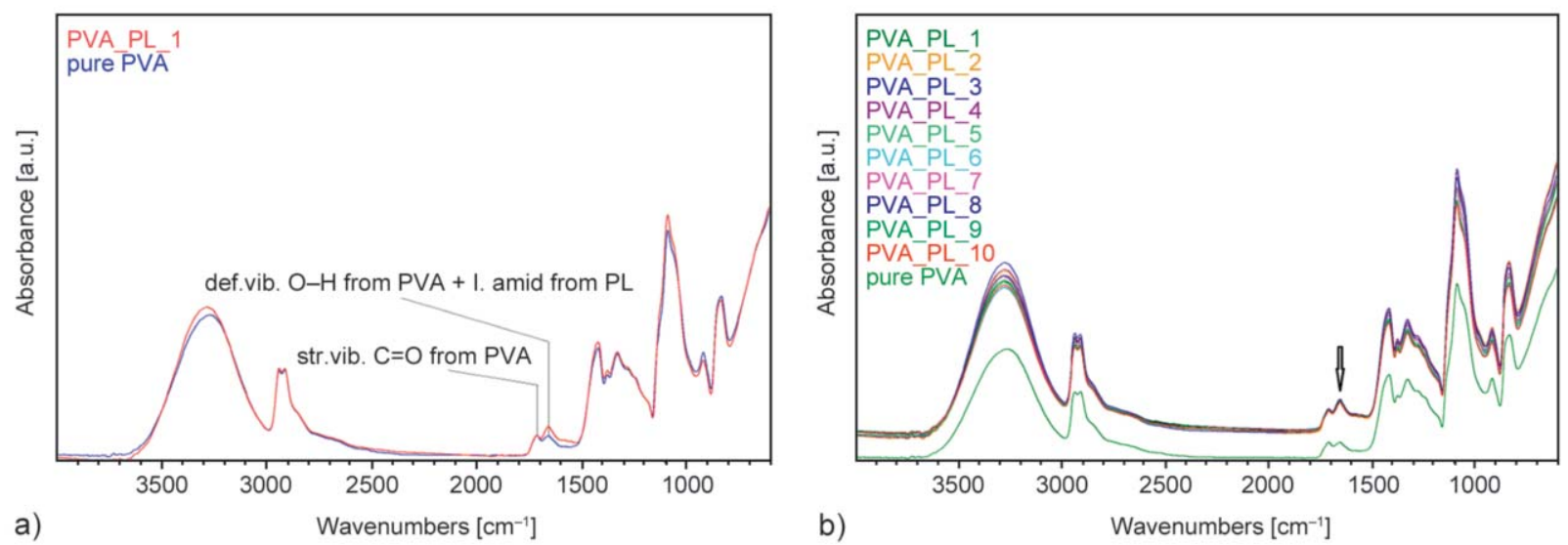

Figure 6. AFT-FTIR analysis of the pure PVA and PVA_PL electrospun materials (a); AFT-FTIR analysis of spectra from 10 different sites of PVA_PL nanofibrous material (b) - an apparent absorbance peak (caused by amide bonds) is indicated. 
its characteristic peaks at $3299 \mathrm{~cm}^{-1}(\mathrm{O}-\mathrm{H}$ stretching), $2917 \mathrm{~cm}^{-1}\left(\mathrm{C}-\mathrm{H}\right.$ stretching from $\left.-\mathrm{CH}_{2}-\right)$, $1427 \mathrm{~cm}^{-1}$ (C-H deformation), and $1085 \mathrm{~cm}^{-1}$ (C-O stretching) [36]. Amide bonds within the protein absorb radiation in multiple regions, including a strong band at $1600-1690 \mathrm{~cm}^{-1}$ [37]. Analysis of a total of 10 sites from different parts of the material (Figure 6b) showed the same signal intensity that corresponds to the protein component.

\subsubsection{Protein release and dissolution of PVA}

One of the main goals of this work was to prepare nanofibrous material, ensuring the gradual release of native proteins (growth factors). This can be achieved through different approaches. Materials prepared by spinning from a polymer-incorporated compound blend usually exhibit a very rapid burst release [9]. This effect is suitable for starting processes, for example, promoting early healing phases of wound healing. The slow (long-term) release is then suitable for the subsequent promotion of cell proliferation and differentiation during the next stages of wound healing processes $[2,38]$. To achieve a slow-release effect, strategies based on the preparation of coresheath materials where the growth factors are located in the core are used $[7,29,39]$ or by incorporating nanoparticles into fibers, wherein the nanoparticles contain a biologically active substance [40]. In watersoluble polymers, it is possible to slow down the release of incorporated compounds by additional crosslinking of the fiber-forming polymers, where the density of the polymer network is a crucial factor [41]. This principle was also used in this work, where the formation of strong non-covalent interactions between PVA molecules leads to the formation of a

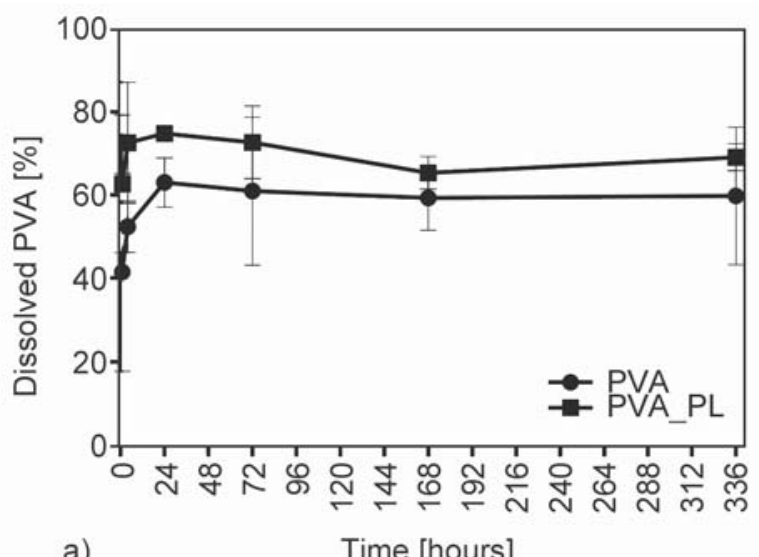

strong physical network [18], which slows the dissolution of PVA and release of incorporated proteins. The release of incorporated proteins at $37^{\circ} \mathrm{C}$ in PBS buffer ( $\mathrm{pH}$ 7.4) over a week was monitored. The release experiments were always performed in tetraplicates - samples from different parts of the material. Protein release is presented a \% of the maximum release amount (protein amount on the last day of measurement). Rapid protein release in the first hours and subsequent slow release over the next 7 days was observed (Figure 7b). The rapid release is due to the release of proteins located on or near the fiber surface. Upon the burst release, the release process is greatly slowed down and sustainable. This is the result of diffusion of the proteins from the physically cross-linked PVA and at the same time the interaction between PVA and proteins. The release process is also related to the dissolution of PVA (Figure 7a). As can be seen from Figure 7, the rapid dissolution of weakly bound PVA molecules occurs. In the case of material without incorporated proteins, approximately $60 \%$ of the material dissolves in this way, and the rest remains stable (visible in the form of a transparent film for months). In the case of protein-loaded materials, the initial solubility rate increases by about $15 \%$; however, the material behaves similarly to the non-additive and does not dissolve anymore after the initial dissolving. Protein addition apparently affects (attenuates) non-binding interactions between PVA molecules [18]. At the same time, a change in the morphology of the material can be observed macroscopically - when it is placed in an aqueous medium, the transparent hydrogel is formed. Due to the technology used (electrospinning from the blend), the resulting type of material is characterized by the burst

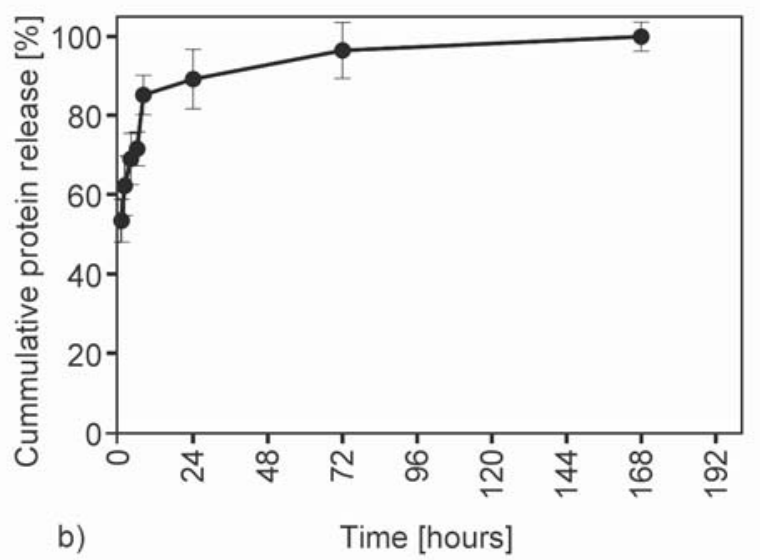

Figure 7. Characterization of the PVA dissolution determined by chromatography (a) and protein release profile (b) determined by spectrophotometry. 
release of the proteins in the first hours [39-41]. In the first hour, $53 \%$ of the proteins are released, and $89 \%$ of the proteins are released within 24 hours. Another $10 \%$ of the proteins are released slowly for at least one week (Figure 7b). Due to the high content of proteins in the original material, it is a slow release of about $0.65 \mathrm{mg}$ of proteins from $1 \mathrm{~g}$ of material during the week. In comparison to studies with coaxial fibers [7, 29] and encapsulated nanoparticles [40] containing growth factors, these are comparable amounts of sustained-release proteins. Thus, the resulting material provides an initial release of a large amount of proteins followed by a slow release of a smaller but still sufficient amount of proteins suitable e.g. for promoting wound healing.

\section{Conclusions}

Large-scale needleless electrospinning technology was adopted to prepare high molecular weight and a high degree of hydrolysis PVA-based nanofiber material with incorporated native growth factors. The process used for the preparation of solutions and subsequent spinning does not affect the activity of the incorporated proteins. The use of high molecular weight PVA $(125000 \mathrm{~g} / \mathrm{mol})$ and a degree of hydrolysis above $98 \%$ effectively reduced the solubility of the resulting material without the need of additional PVA crosslinking. Prepared material exhibits narrow fiber diameter distribution and low defects occurrence, which ensure homogenously distributed proteins within the material. As a result of the reduced PVA solubility, the incorporated proteins are not released immediately. After an initial rapid release of $90 \%$ of the proteins, a slow, sustained release of the proteins occurs for at least one week. Due to the high concentration of incorporated proteins in the entire nanofibrous material, the amount of sequentially released proteins after the initial burst release is still significant. Based on our findings, we believe that the developed material has great potential for use in tissue engineering e.g. to promote healing of large and chronic wounds. The material has been further tested in vitro, and the results of this extensive testing will be published separately.

\section{Acknowledgements}

This work was supported by the Czech Health Research Council, project No NV18-01-00332 and Technical University of Liberec, project No SGS-2019-4085.

\section{References}

[1] Cui W., Zhou Y., Chang J.: Electrospun nanofibrous materials for tissue engineering and drug delivery. Science and Technology of Advanced Materials, 11, 014108/1-014108/11 (2010).

https://doi.org/10.1088/1468-6996/11/1/014108

[2] Zhang Q., Li Y., Lin Z. Y., Wong K. K. Y., Lin M., Yildirimer L., Zhao X.: Electrospun polymeric micro/ nanofibrous scaffolds for long-term drug release and their biomedical applications. Drug Discovery Today, 22, 1351-1366 (2017). https://doi.org/10.1016/j.drudis.2017.05.007

[3] Miguel S. P., Sequeira R. S., Moreira A. F., Cabral C. S. D., Mendonça A. G., Ferreira P., Correia I. J.: An overview of electrospun membranes loaded with bioactive molecules for improving the wound healing process. European Journal of Pharmaceutics and Biopharmaceutics, 139, 1-22 (2019). https://doi.org/10.1016/j.ejpb.2019.03.010

[4] Lai H-J., Kuan C-H., Wu H-C., Tsai J-C., Chen T-M., Hsieh D-J., Wang T-W.: Tailored design of electrospun composite nanofibers with staged release of multiple angiogenic growth factors for chronic wound healing. Acta Biomaterialia, 10, 4156-4166 (2014).

https://doi.org/10.1016/j.actbio.2014.05.001

[5] de Mayo T., Conget P., Becerra-Bayona S., Sossa C. L., Galvis V., Arango-Rodríguez M. L.: The role of bone marrow mesenchymal stromal cell derivatives in skin wound healing in diabetic mice. PLOS ONE, 12, e0177533/1-e0177533/17 (2017).

https://doi.org/10.1371/journal.pone.0177533

[6] Tayalia P., Mooney D. J.: Controlled growth factor delivery for tissue engineering. Advanced Materials, 21, 3269-3285 (2009).

https://doi.org/10.1002/adma.200900241

[7] Yang Y., Xia T., Zhi W., Wei L., Weng J., Zhang C., Li $\mathrm{X}$.: Promotion of skin regeneration in diabetic rats by electrospun core-sheath fibers loaded with basic fibroblast growth factor. Biomaterials, 32, 4243-4254 (2011). https://doi.org/10.1016/j.biomaterials.2011.02.042

[8] Séon-Lutz M., Couffin A-C., Vignoud S., Schlatter G., Hébraud A.: Electrospinning in water and in situ crosslinking of hyaluron ic acid/cyclodextrin nanofibers: Towards wound dressing with controlled drug release. Carbohydrate Polymers, 207, 276-287 (2019). https://doi.org/10.1016/j.carbpol.2018.11.085

[9] Zhang X., Tang K., Zheng X.: Electrospinning and crosslinking of COL/PVA nanofiber-microsphere containing salicylic acid for drug delivery. Journal of Bionic Engineering, 13, 143-149 (2016). https://doi.org/10.1016/S1672-6529(14)60168-2

[10] Saallah S., Naim M. N., Lenggoro I. W., Mokhtar M. N., Abu Bakar N. F., Gen M.: Immobilisation of cyclodextrin glucanotransferase into polyvinyl alcohol (PVA) nanofibres via electrospinning. Biotechnology Reports, 10, 44-48 (2016). https://doi.org/10.1016/j.btre.2016.03.003 
[11] Sequeira R. S., Miguel S. P., Cabral C. S. D., Moreira A. F., Ferreira P., Correia I. J.: Development of a poly (vinyl alcohol)/lysine electrospun membrane-based drug delivery system for improved skin regeneration. International Journal of Pharmaceutics, 570, 118640/1118640/14 (2019).

https://doi.org/10.1016/j.ijpharm.2019.118640

[12] Sóti P. L., Weiser D., Vigh T., Nagy Z. K., Poppe L., Marosi G.: Electrospun polylactic acid and polyvinyl alcohol fibers as efficient and stable nanomaterials for immobilization of lipases. Bioprocess and Biosystems Engineering, 39, 449-459 (2016).

https://doi.org/10.1007/s00449-015-1528-y

[13] Hulupi M., Haryadi H.: Synthesis and characterization of electrospinning PVA nanofiber-crosslinked by glutaraldehyde. Materials Today: Proceedings, 13, 199 204 (2019). https://doi.org/10.1016/j.matpr.2019.03.214

[14] Wu L., Yuan X., Sheng J.: Immobilization of cellulase in nanofibrous PVA membranes by electrospinning. Journal of Membrane Science, 250, 167-173 (2005). https://doi.org/10.1016/j.memsci.2004.10.024

[15] Ben Halima N.: Poly(vinyl alcohol): Review of its promising applications and insights into biodegradation. RSC Advances, 6, 39823-39832 (2016). https://doi.org/10.1039/C6RA05742J

[16] Ratner B. D., Hoffman A. S., Schoen F. J., Lemons J. E.: Biomaterials science: An introduction to materials in medicine. Academic Press, San Diego (2013).

[17] Koski A., Yim K., Shivkumar S.: Effect of molecular weight on fibrous PVA produced by electrospinning. Materials Letters, 58, 493-497 (2004). https://doi.org/10.1016/S0167-577X(03)00532-9

[18] Alves M-H., Jensen B. E. B., Smith A. A. A., Zelikin A. N.: Poly(vinyl alcohol) physical hydrogels: New vista on a long serving biomaterial. Macromolecular Bioscience, 11, 1293-1313 (2011). https://doi.org/10.1002/mabi.201100145

[19] Santos A. M. C., Medeiros E. L. G., Blaker J. J., Medeiros E. S.: Aqueous solution blow spinning of poly (vinyl alcohol) micro- and nanofibers. Materials Letters, 176, 122-126 (2016). https://doi.org/10.1016/j.matlet.2016.04.101

[20] Supaphol P., Chuangchote S.: On the electrospinning of poly(vinyl alcohol) nanofiber mats: A revisit. Journal of Applied Polymer Science, 108, 969-978 (2008). https://doi.org/10.1002/app.27664

[21] Yao L., Haas T. W., Guiseppi-Elie A., Bowlin G. L., Simpson D. G., Wnek G. E.: Electrospinning and stabilization of fully hydrolyzed poly(vinyl alcohol) fibers. Chemistry of Materials, 15, 1860-1864 (2003). https://doi.org/10.1021/cm0210795
[22] Porto M. D. A., dos Santos J. P., Hackbart H., Bruni G. P., Fonseca L. M., da Rosa Zavareze E., Dias A. R. G.: Immobilization of $\alpha$-amylase in ultrafine polyvinyl alcohol (PVA) fibers via electrospinning and their stability on different substrates. International Journal of Biological Macromolecules, 126, 834-841 (2019).

https://doi.org/10.1016/j.ijbiomac.2018.12.263

[23] Yan S., Li X., Dai J., Wang Y., Wang B., Lu Y., Shi J., Huang P., Gong J., Yao Y.: Electrospinning of PVA/ sericin nanofiber and the effect on epithelial-mesenchymal transition of A549 cells. Materials Science and Engineering: C, 79, 436-444 (2017). https://doi.org/10.1016/j.msec.2017.05.048

[24] Yu D-G., Wang M., Li X., Liu X., Zhu L-M., Bligh S. W. A.: Multifluid electrospinning for the generation of complex nanostructures. Wileys Interdisciplinary Reviews: Nanomedicine and Nanobiotechnology, e1601/1e1601/11 (2019).

https://doi.org/10.1002/wnan.1601

[25] Zhao K., Wang W., Yang Y., Wang K., Yu D-G.: From Taylor cone to solid nanofiber in tri-axial electrospinning: Size relationships. Results in Physics, 15, 102770/1-102770/3 (2019). https://doi.org/10.1016/j.rinp.2019.102770

[26] Yang Y., Zhu T., Liu Z., Luo M., Yu D-G., Annie Bligh S. W.: The key role of straight fluid jet in predicting the drug dissolution from electrospun nanofibers. International Journal of Pharmaceutics, 569, 118634/1118634/7 (2019).

https://doi.org/10.1016/j.ijpharm.2019.118634

[27] Bradford M. M.: A rapid and sensitive method for the quantitation of microgram quantities of protein utilizing the principle of protein-dye binding. Analytical Biochemistry, 72, 248-254 (1976). https://doi.org/10.1016/0003-2697(76)90527-3

[28] Bally R. W., Gribnau T. C. J.: Some aspects of the chromogen 3,3',5,5'-tetramethylbenzidine as hydrogen donor in a horseradish peroxidase assay. Clinical Chemistry and Laboratory, 27, 791-796 (1989). https://doi.org/10.1515/cclm.1989.27.10.791

[29] Zhao S., Zhao J., Dong S., Huangfu X., Li B., Yang H., Zhao J., Cui W.: Biological augmentation of rotator cuff repair using bFGF-loaded electrospun poly(lactide-coglycolide) fibrous membranes. International Journal of Nanomedicine, 9, 2373-2385 (2014). https://doi.org/10.2147/IJN.S59536

[30] Rampichová M., Buzgo M., Míčková A., Vocetková K., Sovková V., Lukášová V., Filová E., Rustichelli F., Amler E.: Platelet-functionalized three-dimensional poly- $\varepsilon$-caprolactone fibrous scaffold prepared using centrifugal spinning for delivery of growth factors. International Journal of Nanomedicine, 12, 347-361 (2017).

https://doi.org/10.2147/IJN.S120206 
[31] Buzgo M., Rampichova M., Vocetkova K., Sovkova V., Lukasova V., Doupnik M., Mickova A., Rustichelli F., Amler E.: Emulsion centrifugal spinning for production of 3D drug releasing nanofibres with core/shell structure. RSC Advances, 7, 1215-1228 (2017).

https://doi.org/10.1039/C6RA26606A

[32] Sell S. A., Ericksen J. J., Bowlin G. L.: The incorporation and controlled release of platelet-rich plasma-derived biomolecules from polymeric tissue engineering scaffolds. Polymer International, 61, 1703-1709 (2012). https://doi.org/10.1002/pi.4372

[33] Moreno-Cortez I. E., Romero-García J., GonzálezGonzález V., García-Gutierrez D. I., Garza-Navarro M. A., Cruz-Silva R.: Encapsulation and immobilization of papain in electrospun nanofibrous membranes of PVA cross-linked with glutaraldehyde vapor. Materials Science and Engineering: C, 52, 306-314 (2015). https://doi.org/10.1016/j.msec.2015.03.049

[34] Buzgo M., Greplová J., Soural M., Bezděková D., Míčková A., Kofroňová O., Benada O., Hlaváč J., Amler E.: PVA immunonanofibers with controlled decay. Polymer, 77, 387-398 (2015).

https://doi.org/10.1016/j.polymer.2015.09.018

[35] Hirsch E., Vass P., Démuth B., Pethő Zs., Bitay E., Andersen S. K., Vigh T., Verreck G., Molnár K., Nagy Zs. K., Marosi Gy.: Electrospinning scale-up and formulation development of PVA nanofibers aiming oral delivery of biopharmaceuticals. Express Polymer Letters, 13, 590-603 (2019).

https://doi.org/10.3144/expresspolymlett.2019.50

[36] Santos C., Silva C. J., Büttel Z., Guimarães R., Pereira S. B., Tamagnini P., Zille A.: Preparation and characterization of polysaccharides/PVA blend nanofibrous membranes by electrospinning method. Carbohydrate Polymers, 99, 584-592 (2014).

https://doi.org/10.1016/j.carbpol.2013.09.008
[37] Jackson M., Mantsch H. H.: The use and misuse of FTIR spectroscopy in the determination of protein structure. Critical Reviews in Biochemistry and Molecular Biology, 30, 95-120 (1995). https://doi.org/10.3109/10409239509085140

[38] Bacakova L., Zikmundova M., Pajorova J., Broz A., Filova E., Blanquer A., Matejka R., Stepanovska J., Mikes P., Jencova V., Kostakova E. K., Sinica A.: Nanofibrous scaffolds for skin tissue engineering and wound healing based on synthetic polymers. in 'Applications of nanobiotechnology' (ed.: Stoytcheva M.) IntechOpen, Rijeka, 88744/1-88744/29 (2019).

https://doi.org/10.5772/intechopen.88744

[39] Garcia-Orue I., Gainza G., Gutierrez F. B., Aguirre J. J., Evora C., Pedraz J. L., Hernandez R. M., Delgado A., Igartua M.: Novel nanofibrous dressings containing rhEGF and Aloe vera for wound healing applications. International Journal of Pharmaceutics, 523, 556-566 (2017).

https://doi.org/10.1016/j.ijpharm.2016.11.006

[40] Xie Z., Paras C. B., Weng H., Punnakitikashem P., Su L-C., Vu K., Tang L., Yang J., Nguyen K. T.: Dual growth factor releasing multi-functional nanofibers for wound healing. Acta Biomaterialia, 9, 9351-9359 (2013).

https://doi.org/10.1016/j.actbio.2013.07.030

[41] Del Gaudio C., Baiguera S., Boieri M., Mazzanti B., Ribatti D., Bianco A., Macchiarini P.: Induction of angiogenesis using VEGF releasing genipin-crosslinked electrospun gelatin mats. Biomaterials, 34, 7754-7765 (2013). https://doi.org/10.1016/j.biomaterials.2013.06.040 